\title{
FIGURAS DE LINGUAGEM E O TEXTO PUBLICITÁRIO: MECANISMOS DE PERSUASÃO
}

\author{
ZANELATO, Leandra Silva ${ }^{1}$ \\ COMPARINI, Ana Maria Paulino ${ }^{1}$
}

RESUMO: Este trabalho tem como objetivo principal refletir sobre o uso que se faz das figuras de linguagem no discurso publicitário. Para tanto, utiliza-se do método bibliográfico, percorrendo teorias sobre as figuras de linguagem e as características do texto publicitário, considerando sua capacidade persuasiva. O corpus analisado constitui-se de peças publicitárias, divulgadas na mídia, selecionadas por empregarem alguma figura de linguagem. A análise empreendida destaca a importância do aprendizado deste tema para a educação em geral por despertar a capacidade reflexiva e crítica dos educandos. A pesquisa contribui, neste sentido, ao sugerir que se faça uso, em sala de aula, das figuras de linguagem presentes no discurso publicitário.

Palavras-chave: Gêneros discursivos. Figuras de linguagem. Texto publicitário.

SUMMARY: The main aim of this work is to reflect on the use that is made of the figures of speech in the advertising text. In order to do so, it was used the bibliographic method, traversing theories about discursive genres, the figures of speech, the characteristics of advertising text, which considers its persuasive capacity. The analyzed corpus consists of publicity pieces, published in the current media, selected to compose a work that employs some figures of speech. The undertaken analysis highlights the importance of learning this theme for education in general by awakening the reflective and critical capacity of learners. The research contributes, in this sense, by suggesting that use be made, in the classroom with the figures of speech present in the advertising text.

Keywords: Discursive genres. Figures of Speech. Advertising text.

\section{CONSIDERAÇÕES INICIAIS}

O presente trabalho se propõe a conceituar e analisar anúncios publicitários, tendo como objetivo geral refletir sobre as figuras de linguagem neles utilizadas, ao passo que os objetivos específicos visam compreender a importância da linguagem, identificar as figuras de linguagem e seus recursos característicos em relação ao discurso publicitário e analisar alguns anúncios publicitários com base nas teorias apreendidas.

Para tanto, esta pesquisa fez uso do método bibliográfico, que proporciona ao pesquisador uma melhor aproximação com o tema proposto, por meio da leitura de pesquisas já realizadas e divulgadas, as quais abordam o assunto, propiciando, assim, maior aprofundamento teórico e norteando todo o trabalho. Foram consultados autores consagrados como: Cavalcante (2013), Bakthin (2011, 1998, 1997), Marcuschi (2011, 2005), Koch (2002), Jakobson (1985, 1969), dentre outros. Para a análise do corpus foram utilizadas peças publicitárias, divulgadas na mídia atual, selecionadas por empregarem, em seus textos, alguma figura de linguagem.

Analisar o uso que se faz das figuras de linguagem em textos publicitários justifica-se na medida em que se entende que o ser humano é um ser social, ou seja, ele tem a capacidade de viver em grupo, construindo famílias, cidades e comunidades e, dessa maneira, é preciso que a interação social se dê,

\footnotetext{
${ }^{1}$ Faculdade de Filosofia, Ciências e Letras - Ituverava
} 
também, na esfera da comunicação. Neste contexto, a linguagem aparece como uma forma de socialização entre sujeitos, facilitando o processo de comunicação e as figuras de linguagem, bem como os discursos publicitários, surgem como itens importantes para promover e agilizar todo o processo.

\section{DA IMPORTÂNCIA DA LINGUAGEM PARA A PUBLICIDADE}

Para Bakhtin (1997), a língua é uma forma de interação entre os sujeitos, devendo ser compreendida por sua perspectiva social. Considerando-se a totalidade que abrange, portanto, não se deve limitar a sistemas de formas, nem subjetivismo individualista. Por este motivo, ela deve ser entendida como um processo dialógico e histórico e não como sendo especifica da linguística. Neste contexto, emerge a metalinguística, a qual visa ultrapassar a análise linguística por meio de sua perspectiva estruturalista.

A linguagem ganha sentido apenas por meio da comunicação dialógica, ou seja, pela relação contraditória entre a relação lógica e a dialógica. Essa perspectiva não permite que haja limitação no sentido dado a uma escrita ou a uma fala, por isso, o enunciado já vem com o sentido dado pelo locutor, mas também passa pelo sentido que o ouvinte atribui a ele; portanto, o sujeito se constrói à medida que vai construindo os sentidos daquilo que ele lê, ouve e conversa.

Portanto, pode-se afirmar que a linguagem nada mais é do que a reação daquilo que o sujeito viu ou ouviu, ou seja, é resultado de uma interação. É importante destacar aqui que, para Bakhtin (1998), locutor e ouvinte não se resumem apenas ao diálogo daquele momento, mas sim, aos demais diálogos dos quais participaram ou apenas ouviram no passado ou no presente. A linguagem não existe se não houver interação com o outro. Para o autor,

O discurso vivo e corrente está imediata e diretamente determinado pelo discursoresposta futuro: ele é que provoca esta resposta, pressente-a e baseia-se nela. Ao se constituir na atmosfera do "já-dito", o discurso é orientado ao mesmo tempo para o discurso-resposta que ainda não foi dito, discurso, porém, que foi solicitado a surgir e que já era esperado. (BAKHTIN, 1998, p. 89).

Considerando a linguagem como instrumento de interação e relacionando-se essa concepção à linguagem publicitária, entende-se que esta última é definida como uma forma de comunicação e de interação em massa com a finalidade de persuadir as pessoas a comprarem algum produto ou serviço/ideia. Assim, para Gonçalves (1998, p. 42), "O texto publicitário é uma escultura e comunica no conjunto (...), em que inicialmente o redator joga as ideias conforme as informações do briefing e depois o esculpe como se fosse uma obra de arte; o objetivo é dar-lhe força de comunicar a ideia iconicamente".

Ainda, segundo o autor, as principais características de um texto publicitário são:

- natureza persuasiva, a fim de levar o ouvinte a efetuar a compra, ao passo que, também, deve informar do que se trata tal produto, serviço ou ideologia;

- possui, também, uma natureza autoritária, no sentido de que não há a possibilidade de o ouvinte responder ao anunciante, $\mathrm{e}$

- possui signos verbais e não verbais.

Se a linguagem tem como objetivo comunicar e, sendo o diálogo advindo de interações sociais, as quais permitem a percepção de si mesmo através do outro, sem ela (linguagem) é impossível que ocorra o processo de informar a existência de um produto e suas funções, uma vez que o consumidor desconhece que tal produto existe, torna-se impossível que ele seja adquirido e, ainda, somente por meio da linguagem 
é que o anunciante/vendedor poderá persuadir aos demais da necessidade do produto. Em suma, sem a linguagem, não há possibilidade de a publicidade existir.

\subsection{A função de cada parte que compõe o texto publicitário}

Os textos publicitários possuem características linguísticas próprias, que se dividem em cinco itens: título, imagem, texto, marca, slogan.

O título tem como objetivo chamar a atenção do consumidor para que ele pare e preste atenção ao restante do anúncio e, para atingir tal objetivo, geralmente é apresentado na forma de uma frase criativa. Por esse motivo, o título não tem como função explicar ou informar do que se trata o produto ou serviço logo de início, ele deve focar no receptor. O que explica ser comum o uso de recursos estilísticos e expressivos, visando causar uma comoção no leitor.

Assim, um título deve:

- focar em fatores positivos e agradáveis;

- ter de cinco a sete palavras gramaticais;

- ser breve, mas pode trazer um subtítulo visando complementar o título, também, de maneira breve.

Um anúncio comumente apresenta uma imagem com o objetivo de lhe dar vida, chamando ainda mais a atenção do receptor. A definição de qual imagem deve ser utilizada é um dos segredos do sucesso de um anúncio, podendo ter significado conotativo ou denotativo, mas deve sempre acompanhar o título, de forma que: "visa identificar os elementos da percepção denotativa e icônica e evitar erros de identificação trazidos pelas várias leituras possíveis" (MARTINS FILHO, 1997, p.38).

A imagem é uma comunicação não verbal, portanto, ao ser analisada não se deve considerar as estruturas da linguagem verbal, somente é possível fazê-lo por meio da análise, por exemplo, de luz e de foco.

Já o texto, costuma aparecer logo abaixo da imagem, com o objetivo de informar o receptor sobre o produto ou serviço, bem como se utilizar da persuasão, o que, geralmente, é feito por meio de dados, informações, argumentos ou, até mesmo, por apelo emocional.

O texto não costuma ser muito estendido, tendo no máximo um parágrafo, porém, é possível que haja anúncios com textos maiores, divididos em parágrafos com introdução, desenvolvimento e conclusão. Em ambos os casos, deve haver: a introdução para estimular que o consumidor observe o texto até o final, sempre tentando convencê-lo a adquirir tal produto. Por sua vez, o desenvolvimento deve criar no leitor a certeza de que ele precisa daquilo, utilizando-se de provas racionais e das próprias qualidades do produto. É neste momento que, usualmente, usa-se de apelos emocionais, representados na linguística por meio de: conotação, superlativos e diminutivos, adjetivos positivos, interjeições, exclamações etc. A conclusão do texto publicitário deve instigar o leitor a se transformar em um consumidor, utilizando-se de formas imperativas, sejam elas implícitas (ex: Fumar é prejudicial.) ou explícitas (ex: Beba Coca-Cola!).

Já a marca tem a função de uma assinatura em toda informação que foi passada ao receptor, e pode aparecer como marca mista/corporativa (o logotipo e o nome da empresa), de maneira que seja automaticamente associada a um sinal (desenho) com o nome da marca, como, por exemplo, a logomarca dos produtos Dove que é acompanhada do nome/marca do produto. Ou pode aparecer como marca figurativa, também um desenho ou símbolo, sem qualquer nome da empresa, apenas o desenho, como, por exemplo, os dois peixes que aparecem na propagandas da marca Hering. E, por fim, a marca nominativa, 
em que não se usam símbolos, mas associa-se a marca a uma palavra, podendo ser ao nome da empresa, como, por exemplo, a apresentação da marca Bombril.

Um anúncio possui ainda um slogan, palavra que significa grito de guerra e possui uma origem inglesa. Na publicidade, ela ganhou o sentido de: "frase concisa, marcante, geralmente incisiva, atraente, de fácil percepção e memorização, que apregoa as qualidades e a superioridade de um produto, serviço ou ideia" (RABAÇA; BARBOSA, 1987, p.544).

Portanto, o slogan deve ser breve, rítmico, simpático e compreensível, destacando, assim, de forma sintética, a imagem do produto ou empresa de maneira a fixá-los na mente dos consumidores.

\subsection{As funções da linguagem}

Conforme citado anteriormente, a linguagem acontece por meio de diálogo e interação social, de forma que as estruturas gramaticais recebem um significado social; estas intenções são chamadas de funções da linguagem, por isso há a necessidade de se relacionar a fala e a escrita com o sentido, intenção e/ou significação. É exatamente a significação da linguagem que dará origem às funções da mesma.

O psicólogo Karl Buhler estabelece três fatores de comunicação: destinador, destinatário e contexto. Posteriormente, Jakobson (1969) complementa o modelo de Buhler, entendendo a mensagem através da função exercida por ela.

[...] Assim, as atribuições de sentido, as possibilidades de interpretação — as mais plurais - que se possam deduzir e observar na mensagem estão localizadas primeiramente na própria direção intencional do fator da comunicação, o qual determina o perfil da mensagem, determina sua função, a função de linguagem que marca aquela informação (JAKOBSON, 1969, p. 32).

O que não significa que uma mensagem terá apenas uma função, ela pode ter várias que se interligam em níveis de linguagem diferenciados. Desta forma, são estabelecidas as seguintes funções:

a) Função referencial: diz respeito ao sentido conotativo e denotativo. A conotação é conhecida como sentido figurado (pé de mesa). Por sua vez, a denotação traz o mesmo sentido, porém em contextos distintos, como por exemplo: o pé do animal e o pé do ser humano. Desta forma, na linguagem denotativa, por ter uma função referencial, os signos devem ser organizados em torno do referente, portanto, a denotação possui bases tradicionais, sem duplos sentidos, focando no significado dos objetos, tal linguagem é utilizada no cotidiano (JAKOBSON, 1969).

A função referencial é predominada pelo referente das mensagens. Por este motivo, a linguagem referencial é usada em discursos formais e científicos, uma vez que visam passar a informação de maneira clara, permitindo que o ouvinte adquira conhecimento, tem como característica o uso da $3^{\mathrm{a}}$ pessoa do verbo.

Porém, conforme dito anteriormente, uma mensagem não possui apenas uma função. Por exemplo, em uma poesia, pode-se encontrar a linguagem utilizada com função referencial, no sentido de explicar, descrever um objeto e, ao mesmo tempo, uma linguagem que provoca um determinado sentimento, cruzando-se, assim, a linguagem referencial com a poética.

b) Função emotiva: as mensagens com função emotiva buscam gerar emoções. Comumente, possuem interjeições: "o extrato puramente emotivo da linguagem" (JAKOBSON, 1969, p.34). Também estão repletas de adjetivos, uma vez que representam um sentimento do locutor e, também, caracterizamse pelo uso de advérbios e pontuações. Esta função sempre considera a subjetividade daquele que fala, por isso, o modo como a mensagem é passada é muito importante para a compreensão desta função. A função emotiva aparece em poesias, músicas e arte de forma a transmitir o estado emotivo do emissor do texto. 
Muitas vezes, textos publicitários apresentam, fortemente, elementos da função emotiva, misturados ao caráter conativo que busca levar o leitor ou ouvinte a concordar com a ideia do emissor, comprando-a.

c) Função conativa: acontece, muitas vezes, por meio do diálogo. O locutor direciona sua mensagem diretamente para o ouvinte a fim de tentar convencê-lo de algo, assim, deve ter a capacidade de chamar a atenção do receptor, seja por meio de uma saudação, invocação etc.

Assim, a função conativa tem como base a argumentação e a persuasão. Um exemplo muito relevante de uso da função conativa são os textos publicitários, os quais possuem como objetivo principal persuadir o receptor a comprar um produto ou serviço/ideia, ao mesmo tempo em que trazem um apelo emotivo para sensibilizar o público (o que reforça a afirmativa de que uma função não aparecerá, necessariamente, de forma isolada).

d) Função poética: nesta função o foco está na mensagem que se apresenta de uma maneira diferenciada, mostrando a realidade sensível e concreta, ou seja: "função poética projeta o princípio de equivalência do eixo de seleção no eixo de combinação" (JAKOBSON, 1985, p.29). Portanto, na função poética, a mensagem é trabalhada e, muitas vezes, direcionada para ela mesma.

e) Função metalinguística: a língua é entendida como um código, da qual é decifrada pela história social e individual.

Em outras palavras, a função metalinguística tem como foco o código da mensagem, ou seja, o mais importante (para esta função) é a palavra, de modo que ela seja analisada e explicada.

\subsection{Intertextualidade pela linguagem}

De grande importância para a publicidade, o termo intertextualidade foi introduzido por Kristeva (1974) ao analisar a teoria dialógica de Bakhtin, e abrange a relação do exterior com o interior do texto, entendendo que todo texto teve sua origem a partir de outros textos e, por isto, conversam entre si.

A ligação entre textos independe de seu gênero e recebe três formas intertextuais:

I) Citação: como o nome diz, consiste em citar um texto ou palavras de um texto, não se limita a trazer sempre o mesmo sentido do outro texto, se o mesmo for contestado ou confirmado, ambos geram uma relação intertextual. Na publicidade, este fenômeno pode acontecer não somente com textos escritos, mas também com imagens;

II) Alusão: ao contrário da citação, neste caso, o sentido do texto anterior deve ser mantido e, também, não se replica partes do texto anterior, desta forma: "o texto que alude não constrói um sentido oposto ao do texto aludido" (FIORIN, 2003, p.31). Na publicidade, uma maneira de se usar essa forma é fazendo-se alusão à propaganda da concorrência, assim a marca chama a atenção para si, como uma jogada de marketing;

III) Estilização: trata-se da reprodução do conjunto dos procedimentos do "discurso de outrem, isto é, do estilo de outrem" (FIORIN, 2003, p.31). Ou seja, permite manter ou questionar o sentido do outro texto, desde que mantenha o estilo do texto anterior. Em publicidade, é muito comum que uma empresa mantenha sempre o mesmo estilo de anúncio, principalmente, quando faz campanha de uma linha de produtos.

A intertextualidade é muito utilizada no texto publicitário porque permite explorar a criatividade, relacionando-o a outros textos com o objetivo de cumprir um determinado fim. A sua leitura pode proporcionar um leque de conhecimentos de diversos tipos de textos, levando o leitor a realizar inferências que liguem um texto a outro(s), na busca de compreendê-lo melhor. Segundo Cavalcante (2013, p.146), “em muitos textos, percebem-se indícios tangíveis de uma relação com outros, desde evidências 
tipográficas, [...], até pistas mais sutis que conduzem o leitor à ligação intertextual por meio de inferências".

A exploração da intertextualidade é uma das ferramentas de persuasão mais utilizadas no texto publicitário com o objetivo de conduzir o leitor ao consumo de um produto, despertando o seu senso crítico, ao mesmo tempo em que colabora na difusão da cultura e do conhecimento de mundo.

\section{AS FIGURAS DE LINGUAGEM}

As figuras de linguagem cumprem, tal como Gonzales (2003) sinaliza, a função de redefinir um determinado campo de informação, com vistas a criar efeitos que atraiam a atenção do receptor. Para o autor, existem três principais níveis de figuras de linguagem:

a) Nível Fônico: diz respeito aos sons que a língua oferece, de forma que estes possam apresentar algum significado. Neste nível podemos encontrar: o ritmo, a rima, a aliteração e a onomatopeia. Em relação ao ritmo, destacam-se os textos que mostram alternância entre sílabas átonas e tônicas como, por exemplo, a propaganda da marca de roupa infantil, Lilica Ripilica, que traz os seguintes dizeres: Só uma coisa me deixa mais tiririca do que sonhar que vou ficar nanica: abrir o guarda-roupa e não achar Lilica Ripilica. Nesse texto, as palavras são predominantemente paroxítonas, gerando ritmo e sonoridade quando o consumidor as profere, fazendo com que a memorização das palavras e, consequentemente, da marca, torne-se mais rápida e fácil.

Por sua vez, a rima é a repetição de sons como, por exemplo, na propaganda do serviço de Sedex, oferecido pelos Correios, com o slogan: Encomenda é sedex, o resto é papo furex.

A aliteração trata da repetição de fonemas idênticos ou parecidos (vogais, consoantes ou sílabas) como, por exemplo, no anúncio do antigo sorvete da marca Yopa: Crocante, crocante, muito crocante. Faz até a terra tremer, o uso repetido dos fonemas $\mathrm{cr}$ e $r$ remete ao som que o alimento faz, por ser crocante, ao ser mordido. E, por fim, a onomatopeia, na qual o som da palavra remete ao objeto que ela representa, ou mais detalhadamente trata-se da composição aproximada de um som natural.

b) Nível Gramatical: é utilizado para dar efeitos de sentido, usando-se classes gramaticais com construções sintáticas diferenciadas, de forma a chamar a atenção do leitor. São elas: gradação, paralelismo sintático, repetição, paronomásia, enumeração caótica, quiasmo.

A gradação diz respeito a elementos que são alocados, de forma gradativa, com o objetivo de dar ênfase ao último elemento como, por exemplo, no texto de uma propaganda da cerveja Antártica: A garrafa é bronze, o rótulo é prata, o líquido é ouro. Seus dizeres mostram, ao mesmo tempo, a mesma construção sintática (paralelismo sintático) e uma gradação crescente em termos de valores: do bronze, passando pela prata, ao ouro.

A repetição, por sua vez, objetiva mostrar insistência, a reiteração ordenada de sons consonantais iguais, pode ser usada, até mesmo, para ênfase à mensagem, por exemplo, na propaganda do chocolate Batom, a qual dizia: Compre Batom. Compre Batom. Compre Batom.

A paronomásia, também conhecida como trocadilho, caracteriza-se pela utilização de palavras parônimas (palavras com significados diferentes que se escrevem e se pronunciam de forma parecida), e é muito utilizada nas propagandas. Como, por exemplo, no anúncio de uma determinada marca de liquidificador aparece o seguinte texto: Além de resistentes são também irresistíveis, utilizando-se um trocadilho entre as palavras resistentes e irresistiveis.

Há, ainda, a enumeração caótica, a qual se utiliza de palavras de forma aleatória e que aparentam não ter sentido algum, mas que se associadas ao produto, geram sentido como, por exemplo, na publicidade do Ticket Restaurante, cujo texto aparece reproduzido abaixo: 
Brasil do Guimarães, de Machado, de Amado, de Samba, de Bamba, de Mané, de Feijão, de João, de Zé, de Praia, de Mangueira, de Capoeira, de Cachaça, de Cartola, de Bola, de Chorinho, de Cuíca, do Chico, da Zica, da Paulista, da Aquarela, do Pandeiro, do Mulato Inzoneiro, do Torresmo, do Virado, dos Mil Tons. Brasil do Ticket Restaurante.

Neste exemplo, os elementos que, aparentemente são enumerados de forma aleatória, ao final do anúncio, geram sentido no momento em que aparece o nome do restaurante Ticket do Brasil, mostrando, assim, a complexidade da cultura brasileira.

Por fim, o quiasmo, trata-se da ordem de duas frases estruturadas de maneira cruzada, formando, dessa forma, um paralelo; objetiva dar contraste aos significados como, por exemplo, na propaganda da revista Veja, que traz os seguintes dizeres:

Veja não tira os olhos do Brasil. E o Brasil não tira os olhos de Veja.

Neste caso, há um contraste, uma oposição no enunciado: Veja e Brasil trocam de posição na frase, mudando suas funções sintáticas e, consequentemente, suas funções semânticas também.

c) Nivel Semântico: são formas de alteração do sentido das palavras ligadas ao valor afetivo ou socialmente aceitável. Dentro desse nível, encontramos a metáfora, na qual há uma intersecção entre pontos semelhantes de uma imagem ou figura com o sentido da palavra, como no exemplo da propaganda abaixo:

Figura 1: Metáfora

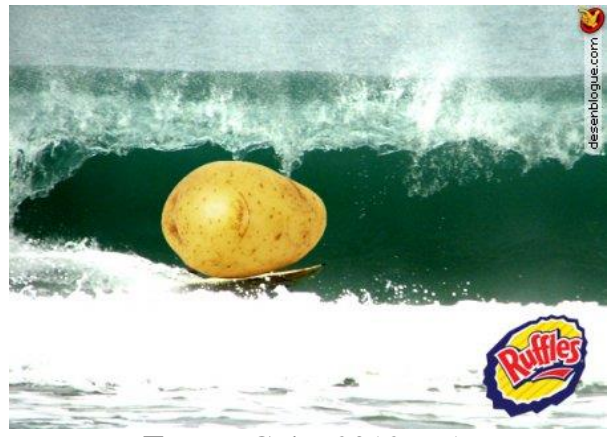

Fonte: Galo, 2012, p.1.

Nesse caso, a imagem é uma metáfora do slogan da marca: Batata da onda, na qual a ligação de um elemento ao outro se torna subjetivo, ou seja, a imagem de uma batata surfando deve remeter à frase do slogan Batata da onda.

Outra figura de linguagem de nível semântico é a metonímia; trata-se de um recurso da retórica a qual representa uma palavra que não está no seu contexto semântico normal, esse fenômeno acontece pelo fato de tal palavra ter uma relação objetiva com o significado conceitual, material ou de contiguidade; mas ao contrário da metáfora, não possui uma ligação subjetiva, mas sim, objetiva. Veja o exemplo a seguir: 
Figura 2: Metonímia

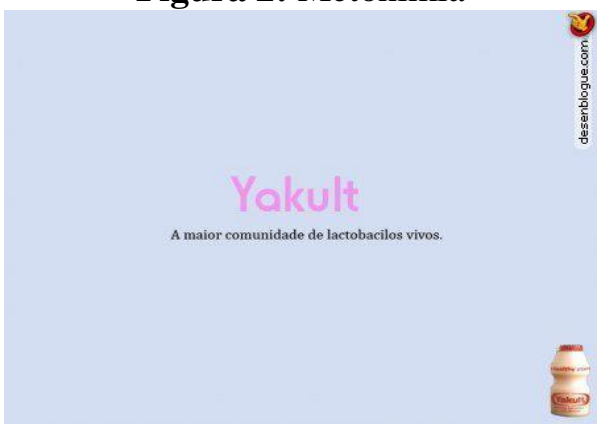

Fonte: Thunter, 2009, p. 1.

A propaganda acima remete ao conhecido símbolo da rede social, o Orkut, de modo que o receptor se lembre de forma objetiva de tal marca.

Outra figura de linguagem do campo semântico é a antítese; essa palavra vem do grego, significa oposto à criação e representa um estilo de linguagem que expõe ideias opostas, sendo que isso acontece quando expressões e palavras de sentidos divergentes se aproximam. A antítese lida com elementos (palavras, ideias, figuras etc.) opostos, como na imagem abaixo:

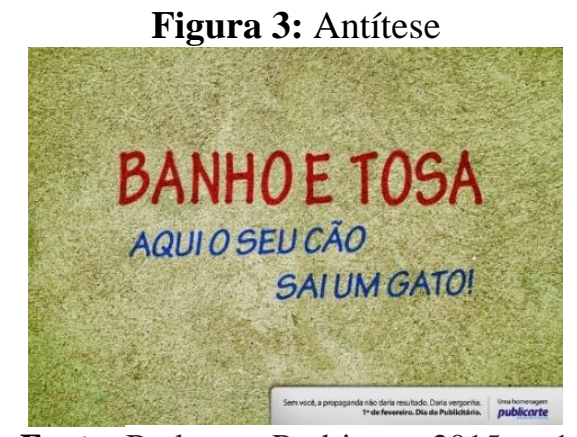

Fonte: Barbosa e Rodrigues, 2015, p. 1

Nesse caso, a propaganda fala de banho e tosa para o cachorro que será tão bem tratado que sairá de lá como um gato (remetendo à beleza de um ser), sendo que a palavra gato, aqui, representa oposição à palavra cachorro.

Há, ainda, o paradoxo, que também mostra a noção de oposição, porém não se limita à oposição das palavras, mas sim, atinge a oposição de ideias; por isso, diferencia-se da antítese: as oposições apresentadas não anulam uma à outra como no caso anterior, mas são diferenças que coexistem. Como, por exemplo, em uma propaganda da Philips, sobre televisores, utiliza-se a frase: Uma grande TV não precisa ser uma TV grande.

Percebe-se que a TV pode ser de tamanho reduzido/pequeno, mas grande na qualidade: pequeno versus grande é a oposição, os dois valores podem coexistir, sem se anularem.

A hipérbole, outra figura de linguagem que também é muito usada no campo semântico, trata-se da ênfase em uma expressão com um exagero da significação linguística, tem o objetivo de intensificar, exagerar a realidade, como no exemplo abaixo: 
Figura 4: Hipérbole

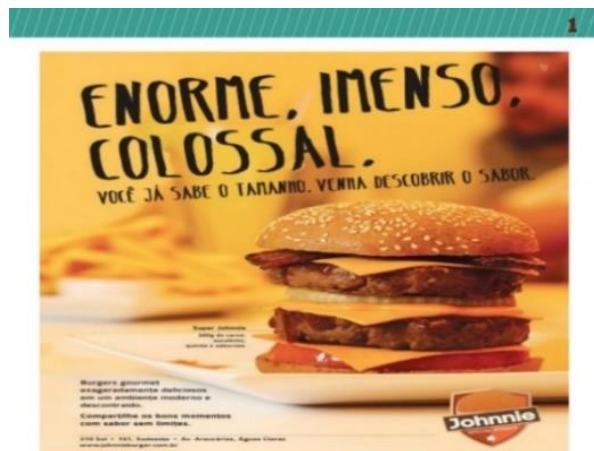

Fonte: Guia do Estudante, 2015, p. 1.

A propaganda acima se refere ao lanche como colossal, como se ele tivesse um tamanho fora do comum, denotando um exagero sobre o produto.

Dentro do nível semântico, há, ainda, outros tipos de figuras de linguagem, tais como a ironia, a qual objetiva afirmar algo quando, na verdade, a intenção é negá-lo; existe também a sinestesia, muito utilizada na publicidade, pois objetiva mexer com as sensações, com os sentidos: visão, olfato, paladar, tato e audição. Há, além disso, o eufemismo, o qual substitui uma palavra considerada dura/áspera por uma mais branda/macia para não causar tanto impacto como, por exemplo, ao se anunciar um creme antirrugas para os idosos, utiliza-se palavras como creme antissinais, evitando-se, assim, aquelas que possam soar de forma agressiva ou, até mesmo, de maneira preconceituosa.

\section{ANÁLISE DO CORPUS}

Embora seja possível notar que são inúmeras as figuras de linguagens existentes, por questões metodológicas e de extensão do trabalho, o número delas foi restringido para efeito de análise. Tal escolha não prescinde, de modo algum, do uso de outras figuras igualmente relevantes para o estudo do texto publicitário. Assim, foram selecionadas as seguintes figuras de linguagem para análise nesta seção: paronomásia, onomatopeia, hipérbole, ironia, sinestesia, metáfora, antítese e eufemismo.

Figura 5: Propaganda de perfume

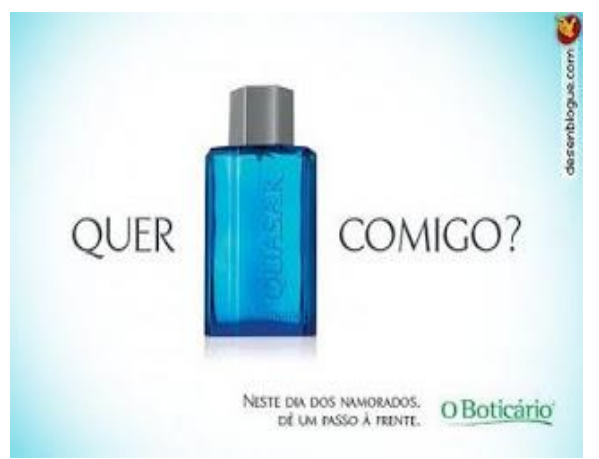

Fonte: Lima, 2015, p.1.
Figura 6: Propaganda de empresa de financiamento

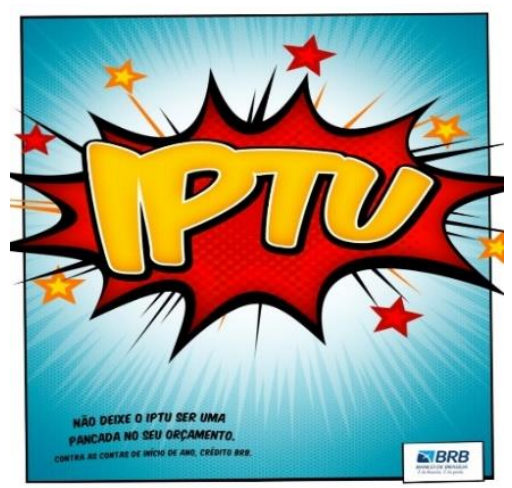

Fonte: Prêmio Colunistas de Brasília, 2013, p. 1.

A figura 5 mostra uma propaganda que tem como tema o dia dos namorados; a marca é $O$ Boticário, que se identifica no canto direito da imagem com seu logotipo. Tem como público-alvo os casais, possui cores suaves para dar um tom mais romântico e foi veiculada em revistas e outdoors para 
divulgar o perfume Quasar. No título: Quer Quasar comigo? aparece o fenômeno da paronomásia, que representa um trocadilho do verbo casar com o nome do perfume "Quasar". Mostra, também, o uso da figura de linguagem com função poética, uma vez que promove uma brincadeira com o código transmitido. O slogan: Neste dia dos namorados, dê um passo à frente mostra-se persuasivo: se a pessoa comprar o perfume anunciado, ela estará dando um passo à frente, como faz a noiva ao entrar na igreja e caminhar até o altar, para se encontrar com seu futuro marido.

A propaganda ilustrada pela figura 6, de uma empresa de financiamento, Banco de Brasília, utiliza-se da persuasão quando tenta levar o público a comprar cartas de crédito para pagar as contas de começo de ano, as quais geralmente são os impostos cobrados, dentre eles o IPTU (Imposto Predial e Territorial Urbano). Desta forma, utiliza-se de uma onomatopeia para demonstrar a palavra IPTU, como uma forma de representar o barulho de um soco (o que, em geral, é representado pela palavra pow). É possível visualizar, também, o recurso da intertextualidade, relacionando a publicidade aos textos das histórias em quadrinhos: as próprias cores da imagem lembram os quadrinhos de super-heróis. $\mathrm{O}$ anúncio tem como público-alvo pessoas que possuem casa própria e que, portanto, pagam o referido imposto. Essa propaganda foi vinculada na mídia impressa: outdoors e revistas e tem como slogan Não deixe o IPTU ser uma pancada no orçamento, compondo a onomatopeia citada acima. No canto direito, aparece o logotipo da empresa.

Figura 7: Propaganda de produto alimentício

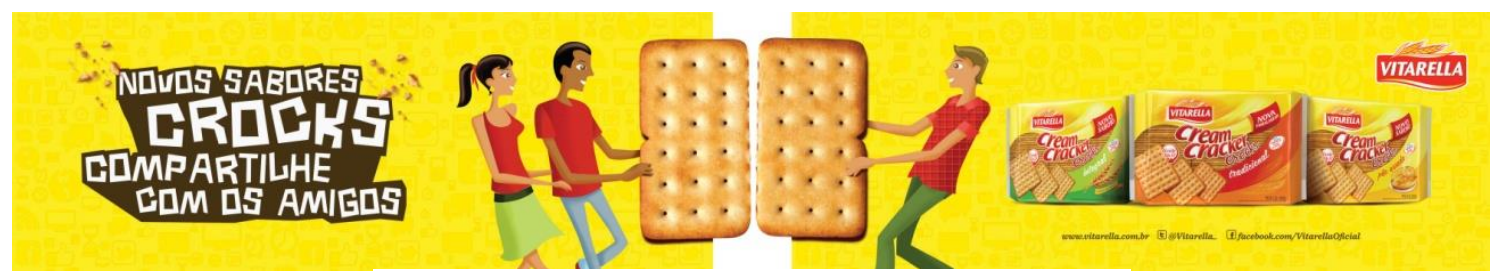

Fonte: Prêmio Colunistas de propaganda, 2012, p.1

Esta propaganda apresenta o biscoito salgado da marca Vitarella e seu slogan traz a frase: Novos sabores crocks. Compartilhe com os amigos. Nota-se que a empresa nomeou os novos sabores dos biscoitos como Crocks, os quais dão a sensação de crocância, representando então uma onomatopeia. O anúncio possui um fundo amarelo, para chamar a atenção do público, suscitando fome e desejo de comer. O slogan em branco, com uma fonte chamativa, também remete à crocância. O enunciado Compartilhe com os amigos faz referência às redes sociais, nas quais as pessoas compartilham tudo: fases da vida, momentos alegres e tristes, o que comem ou bebem etc. Ao lado, imagens do produto com novos sabores e no canto superior direito o logotipo da empresa.

Figura 8: Propaganda de facas

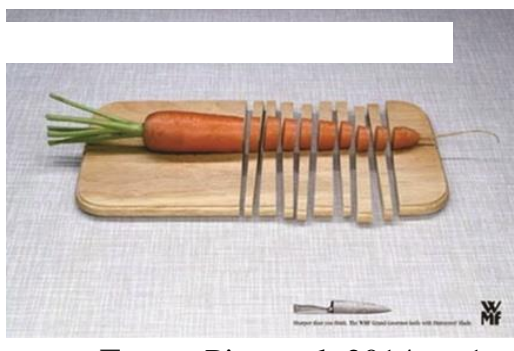

Fonte: Pimentel, 2014, p. 1
Figura 9: Anúncio de escova de dentes

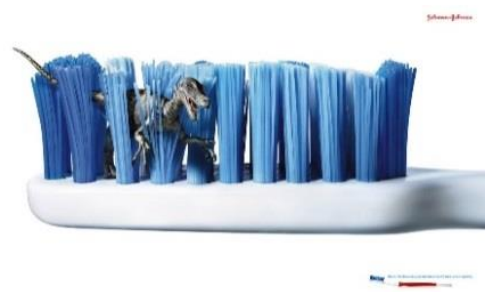

Fonte: Alvarez, 2011, p. 1

A figura 8 trata da marca de facas MF e visa a retratar a excelente afiação do produto, tendo como 
público alvo donas de casa, cozinheiros, proprietários de restaurantes, chefes de cozinha e demais pessoas que lidam com o preparo e manejo de alimentos. As cores de fundo do anúncio são claras (cinza e branco), para poder destacar a imagem central, que apresenta uma cenoura fatiada junto com a tábua de corte, significando que a faca é tão afiada que corta até mesmo a tábua. A figura de linguagem utilizada é a hipérbole, que mostra o exagero no anúncio, a fim de persuadir o consumidor em relação à potência da faca. Foi veiculada na mídia impressa, por meio de outdoors e revistas.

A figura 9 acima trata de um produto da famosa marca Johnson \& Johnson e mostra uma escova dental em tamanho ampliado e, dentro dela, um dinossauro. Desta forma, o anunciante pretende mostrar que a escova tira até as maiores sujeiras e os maiores germes existentes na boca, por ser muito eficaz. Assim, a imagem fala por si só, utilizando-se de uma hipérbole, em que há um exagero no tamanho do produto e, também, no tipo de sujeira que está combatendo. Comentários, textos e slogans são dispensados, apenas no canto direito aparece a marca que, sozinha, já representa bem a empresa, possui, ainda, o fundo branco, dando maior ênfase ao produto, elementos e figura de linguagem utilizados como fortes instrumentos de persuasão.

Figura 10: Publicidade de um chocolate
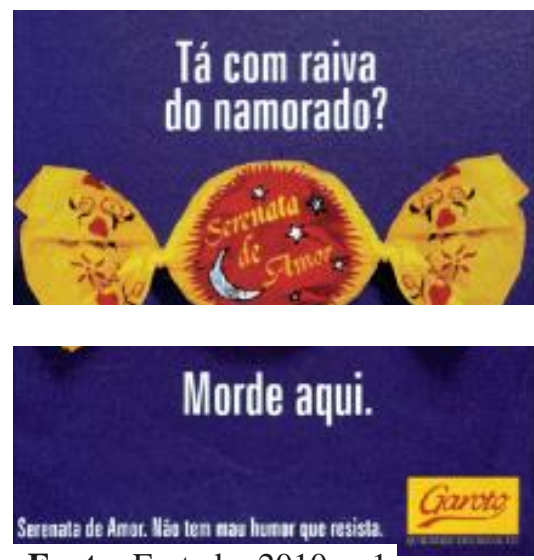

Fonte: Furtado, 2010, p.1.
Figura 11: Propaganda Seara

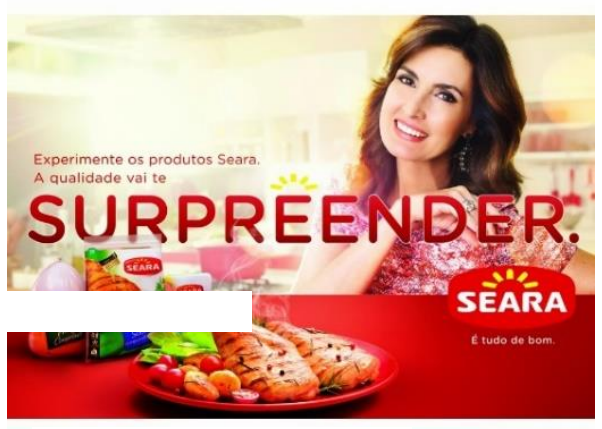

Fonte: Dores, 2017, p. 2.

A propaganda da figura 10 trata de um chocolate, mais precisamente do bombom Serenata de Amor, e tem como público-alvo as mulheres, $\mathrm{O}$ objetivo principal do texto é persuadi-las a comprarem o bombom e dar uma mordida para passar a raiva que sentem de seus namorados (como se estivessem mordendo os próprios namorados). Possui cores quentes, que instigam a fome, ao mesmo tempo em que chamam a atenção. Traz, ainda, uma assinatura, no final do anúncio, no canto direito em que se vê o logotipo com a marca da empresa.

Seu título: Está com raiva do namorado? É convidativo e desperta a curiosidade dos leitores para o restante da mensagem a ser transmitida. Já o complemento do texto se utiliza da função conativa da linguagem, na tentativa de persuadir o leitor de forma mais direta, por meio do uso de uma frase no modo imperativo: Morde aqui. Por sua vez, o slogan: Não tem mau humor que resista, também, demonstra ironia, uma vez que, culturalmente, a mulher é taxada como aquela que tem um temperamento raivoso para com o namorado/homem, principalmente durante um determinado período de seu ciclo mensal (chamado de TPM - Tensão Pré-Menstrual), sendo o chocolate, culturalmente, conhecido por aliviar esses sintomas. Há, ainda, uma tentativa de persuasão bem como um apelo emocional, dizendo que se comprar tal produto não haverá mau humor.

A propaganda da figura 11, de uma marca conhecida, utiliza-se da persuasão por meio do uso que faz da imagem que nela aparece: uma jornalista famosa e com grande credibilidade na mídia, mulher, mãe 
e, supostamente, dona de casa. Ao associar a imagem de Fátima Bernardes à imagem do alimento, a intenção é persuadir o consumidor sobre a confiança que se pode ter em relação à qualidade do produto. Tem como público-alvo todas as pessoas que consomem carne e utiliza-se de um argumento lógico ao divulgar o slogan: Experimente os produtos Seara. A qualidade vai te surpreender. A imagem do prato sobre a mesa, saindo fumaça pretende estimular, principalmente, dois sentidos: olfato e paladar, ao passo que o fundo permanece vermelho, a mesma cor do logotipo do produto, a qual, além de remeter à sensação de fome, também, remete à marca. Essa mistura de sentidos representa a figura de linguagem chamada sinestesia.

Figura 12: Propaganda Tramontina

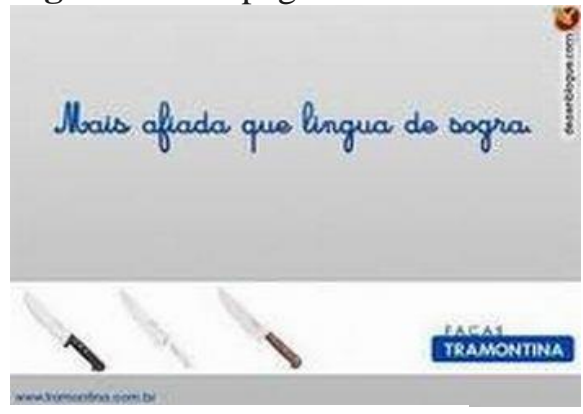

Fonte: Ferreira, 2010, p. 2.
Figura 13: Propaganda de maionese

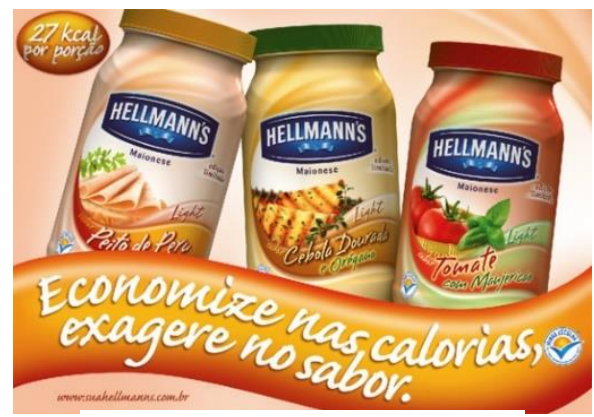

Fonte: Modesto, 2008, p.1.

A figura 12 acima possui cores neutras, de modo a destacar a frase, a imagem do produto e o logotipo da marca, seu slogan: Mais afiada que língua de sogra apresenta o uso da figura de linguagem denominada metáfora, já que faz uma comparação da afiação da faca com a língua de uma sogra, vista, popularmente, como uma pessoa que critica muito. Assim, em sentido figurado, língua afiada é aquela pessoa que critica tanto que pode até cortar, superada somente pelas facas da Tramontina. O logotipo aparece no canto direito da peça publicitária, destacado em azul, ao lado da imagem do produto, que é apresentado com variedade de cor.

A propaganda da figura 13 utiliza-se da figura de linguagem antítese, uma vez que exprime a ideia de palavras opostas: economizar e exagerar. As cores desta propaganda tendem para o vermelho, com um fundo rosado bem claro para destacar a imagem do produto e apresentar os novos sabores. $\mathrm{O}$ slogan: Economize nas calorias, exagere no sabor está escrito sob uma faixa alaranjada e vermelha com as letras em branco, também para dar destaque e por serem tons de cores que ativam a fome e a sede no cérebro. Portanto, os elementos utilizados procuram persuadir o consumidor a comprar o produto para saciar sua fome, com exagero de sabor e economia na ingestão de calorias.

Figura 14: Propaganda do governo

- DEPOIS DO CARNAVAL

NÃO ADIANTA CHORAR

(PELO LEITE DERRAMADO...

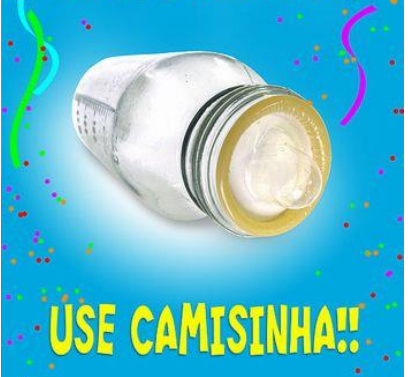

Fonte: Oliveira, 2011, p.2. 
Com o slogan: Depois do carnaval, não adianta chorar o leite derramado, a propaganda utiliza-se da figura de linguagem chamada eufemismo, uma vez que passa a mensagem de modo amenizado, de uma forma mais leve, empregando a imagem de uma mamadeira, dando uma noção do que pode acontecer se as pessoas não fizerem uso da camisinha. A campanha é um alerta, para que a população use camisinha durante o período de carnaval, para que não ocorra a gravidez indesejada e não planejada, de maneira desestruturada. Esse anúncio possui um fundo azul forte para chamar a atenção do público, tem ainda desenhos de confetes e serpentinas, que remetem ao carnaval, para, também, chamar a atenção do público alvo. E, abaixo da imagem, fazendo-se valer da função da linguagem conativa, empregou-se o modo imperativo na frase Use camisinha, mensagem final, que soa, propositalmente, como um conselho.

Considerando que as peças publicitárias podem ser ricos instrumentos a serem utilizados no processo de ensino-aprendizagem, entendemos que o trabalho do professor pode ser enriquecido com o uso efetivo de propagandas e publicidades em sala de aula.

\section{CONSIDERAÇÕES FINAIS}

Considerando a linguagem como instrumento de interação, buscamos conceituar e analisar o gênero discursivo publicitário, refletindo sobre o uso que se faz das figuras de linguagem nele utilizadas. Para tanto, optamos por uma abordagem que nos permitisse conceituar o gênero proposto para análise, discutir a importância da linguagem e identificar as figuras de linguagem e seus recursos característicos.

A análise dos dados demonstrou que o ensino da linguagem compreende a necessidade de aprender a elaborar e traduzir os códigos da mesma, porém, é preciso ir além do trabalho como um simples gesto automático, gerando a possibilidade da compreensão dos fatores influenciadores da linguagem. Para tanto, na leitura de uma mensagem, seja ela oral ou escrita, deve-se considerar os fatores que envolvem sua criação e transmissão, tais como: o contexto social, cultural e econômico.

Diante da necessidade de entender a linguagem em seu contexto social, devemos considerar as relações sociais entre transmissor e ouvinte, o ambiente, as pessoas que participam da interação em que emerge a figura de linguagem, proporcionando maior criatividade e possibilidades à expressão de sentimentos e pensamentos.

Quanto ao gênero publicitário, é notório que está inserido no cotidiano da sociedade, já que estamos falando de uma sociedade capitalista que visa a produção e o consumo de bens materiais e imateriais. Perante tamanha competição do mercado, o gênero em questão torna-se cada vez mais criativo e rico para a reflexão e compreensão, sendo utilizados recursos estilísticos com base na retórica aristotélica atingindo, assim, o objetivo de persuadir o público para a compra de tais produtos.

Dessa forma, é preciso que se percebam algumas características linguísticas consideradas próprias do texto publicitário, entendendo que ele deve conter: título, imagem, texto, marca, slogan, pois, quando se trata de persuadir o outro, todos os recursos são bem-vindos para a elaboração do texto publicitário. Constatamos, ainda, que a análise dos textos que compuseram o corpus, aqui descrito, revelou um número expressivo e significante de peças publicitárias em que as figuras de linguagem são utilizadas como elementos retóricos e de persuasão.

Dada à especificidade de um estudo mais aprofundado de estratégias discursivas de natureza persuasiva, apontamos como temática para pesquisas futuras, a análise da manifestação persuasiva no discurso publicitário. 


\section{REFERÊNCIAS}

ALVAREZ, C. Retórica visual. 2011. Disponível em: https://br.pinterest.com/pin/536702480574753332/ . Acesso em: 13 out. 2017.

BAKTHIN, M. Estética da criação verbal. 6.ed. São Paulo: Martins Fontes, 2011.

BAKTHIN, M. O discurso no romance. In: BAKTHIN, M. Questões de literatura e de estética: a teoria do romance (1934-1935). Tradução por Bernadini et al. 4.ed. São Paulo: Unesp,1998.

BAKTHIN, M. Problemas da poética de Dostoievski. 2.ed. Tradução por Paulo Bezerra. Rio de Janeiro: Forense Universitária, 1997.

BARBOSA, L.; RODRIGUES, V. Imaginário criativo. 2015. Disponível em: http://imaginariocriativopuc.blogspot.com.br/2015/04/aula-08-louyse-barbosa-e-vanessa.html . Acesso: em 31 set. 2017.

CAVALCANTE, M.M. Os sentidos do texto. São Paulo: Contexto, 2013.

DORES, K. Fátima Bernardes estreia para Seara. 2014. Disponível em:

<http://propmark.com.br/anunciantes/fatima-bernardes-estreia-para-seara>. Acesso em: 31 out. 2017.

FERREIRA, C.S. A conotação presente no discurso. 2010. Disponível em:

http://portaldoprofessor.mec.gov.br/fichaTecnicaAula.html? aula=24746 . Acesso em: 31 out. 2017.

FIORIN, J.L. Polifonia textual e discursiva. In: BARROS, D.L.P. de; FIORIN, J.L. (Org.). Dialogismo, polifonia, intertextualidade: em torno de Bakhtin. 2.ed. São Paulo: Universidade de São Paulo, 2003.

FURTADO, C. Enredado na língua portuguesa. 2010. Disponível em:

http://enredadonotexto.blogspot.com.br/2010/09/complemento-nominal.html. Acesso em: 31 out. 2017.

GALO, M. E essa tal de metáfora hein? 2012. Disponível em: <http://mazah-

galo.blogspot.com.br/2012/06/e-essa-tal-de-metafora-hein.html>. Acesso em: 31 set. 2017.

GONÇALVES, A. A produção no mundo da línguagem. Uma reflexão sobre o ensino de Língua Portuguesa nos cursos de Publicidade e Propaganda. Revista Imes Superior de São Caetano do Sul. Ano XV, n. 43, p.40, 1998.

GONZALES, L. Linguagem publicitária: análise e produção. São Paulo: Arte e Ciência, 2003. Disponível em: https://books.google.com.br/books?id=Gwu3aNuOl4C\&printsec=frontcover\&hl=pt$\mathrm{BR} \&$ source=gbs_ge_summary_r\&cad=0\#v=onepage\&q=sumário\&f=false . Acesso em: 9 set. 2017.

GUIA DO ESTUDANTE. Figuras de linguagem. 2015. Disponível em: https://pt.slideshare.net/clauheloisa/figuras-de-lgg-exerc-2-pdf . Acesso em: 31 set. 2017.

HALLIDAY, M. A. K. The functional basis of language. In: BERNSTEIN, B. (Ed.). Class, codes and control London: Routledge and Kegan Paul, 1973.

JAKOBSON, R. Diálogos. São Paulo, Cultrix, 1985.

JAKOBSON, R. Lingüística e comunicação. São Paulo, Cultrix, 1969.

KOCH, I.G.V. Desvendando os segredos do texto. São Paulo: Cortez, 2002.

KRISTEVA, J. Introdução à semanálise. São Paulo: Perspectiva, 1974. 
LIMA, J.R. Funções da linguagem. 2015. Disponível em: https://pt.slideshare.net/literaturaeshow/funesda-linguagem-48588939. Acesso em: 31 set. 2017.

MARCUSCHI, L. A. Gêneros textuais: configuração, dinamicidade e circulação. In: KARWOSKI, A. M.; GAYDECZKA, B.; BRITO, K. S. (Orgs.). Gêneros textuais: reflexões e ensino. 4.ed. São Paulo:

Parábola, 2011.

MARCUSCHI, L. A. Gêneros textuais: definição e funcionalidade. In: DIONÍSIO, A. P.; MACHADO, A. R.; BEZERRA, M. A. (Org.). Gêneros textuais e ensino. 4. ed. Rio de Janeiro: Lucerna, 2005.

MARTINS FILHO, E. Manual de redação e estilo de O Estado de S. Paulo. 3.ed. São Paulo: O Estado de São Paulo, 1997.

MODESTO, H. Unilever lança edição limitada de maionese Hellmann's. 2008. Disponível em: https://www.mundodomarketing.com.br /ultimas-noticias/6332/unilever-lanca-edicao-limitada-demaionesehellmanns.html . Acesso em: 31 out. 2017.

OLIVEIRA, R.S.de. O carnaval na cultura brasileira. 2011. Disponível em: http://portaldoprofessor.mec.gov.br/fichaTecnicaAula.html?pagina=espaco/visualizar_aula\&aula=36109\& secao=espaco\&request locale=es . Acesso em: 31 out. 2017.

PIMENTEL, C. Figuras de linguagem. 2014. Disponível em:

$<$ http://educacao.globo.com/portugues/assunto/figuras-de-linguagem/hiperbole. html>. Acesso em: 30 set. 2017.

PRÊMIO colunistas de propaganda, Brasília, 2013. 2013. Disponível em: http://www.colunistas.com/anos/pc2013/df/html/pc2013df-pr_impressa-premiados.html . Acesso em: 30 set. 2017.

PRÊMIO colunistas de propaganda Brasília 2012. 2013. Disponível em: http://www.colunistas.com/anos/pc2012/nn/html/pc2012prnn_especiais-premiados.html . Acesso em: 30 set. 2017.

RABAÇA, C.A.; BARBOSA, G.G. Dicionário de comunicação. São Paulo: Ática, 1987.

THUNTER. A propaganda é a alma do negócio. 2009. Disponível em:

https://amorcomhumor.wordpress.com/2009/11/29/ . Acesso em: 31 set. 2017. 